Akdoğan, Nuri (2019). “Düşük Statülü Grupların Yüksek Statülü Gruplara Yönelik Olumlu Tutumu". Uludağ Üniversitesi Fen-Edebiyat Fakültesi Sosyal Bilimler Dergisi, C. 20, S. 37, s. 711-737.

DOI: 10.21550/sosbilder.469991 Araştırma Makalesi

\title{
DÜŞÜK STATÜLÜ GRUPLARIN YÜKSEK STATÜLÜ GRUPLARA YÖNELIK OLUMLU TUTUMU
}

Nuri AKDOĞAN*

Gönderim Tarihi: Ekim 2018

Kabul Tarihi: Şubat 2019

\section{ÖZET}

$B u$ çalışmanın temel amaçlarından biri toplumsal yapı içerisinde düşük sosyal konumda bulunan grupların üyelerinin yüksek sosyal konumdaki gruplara yönelik dış grup tarafgirliği olarak kavramlaştırılan tutumuna farklı açıklama getiren araştırma bulgularını derlemek ve bu bulguları özsaygl, kontrol algısı, süreklilik kimlik motivasyonlar temelinde tartışmaktır. Çalı̧̧ma kapsamında derlenen araştırma bulguları Temel Uyuşma Yanlıllğı (TUY) ve Terör Yönetimi Kuramı (TYK) bağlamında ele alınmıştır. TUY eğilimi ile ilgili yapılan çalışmaların bulguları düşük statülü grupların içinde bulunduğu dezavantajlı konumun sorumluluğunu kendilerine yüklemelerinin nedeninin temel bir motivasyon olan kontrol algisl ile ilgili olabileceğini; üst statülü grupların konumlarlyla ilgili başarılarını onların içsel özelliklerine atfetmelerinin ise onlardan gelebilecek olast tehditleri öngörme ve bunlara karşı tedbirli olmayla alakalı olabileceğini göstermektedir. TYK bağlamında incelenen çalışma bulguları da düşük statülü grupların sosyal eşitsizlik üreten sistemi (toplumsal yapıyı) destekleme sebebinin bu yapının kendilerinin hayatına bir düzen, süreklilik ve anlam getirerek başta özsaygı olmak üzere çeşitli ihtiyaçlarını tatmin etmesi ile ilgili olabileceğini göstermektedir.

Anahtar Kelimeler: diş grup tarafgirliği, kimlik motivasyonlarl, benlik değerlendirme motivasyonu, temel uyuşma yanlılı̆̆l, terör yönetimi kuramı

Arş. Gör., Dicle Üniversitesi Edebiyat Fakültesi Psikoloji Bölümü, nuriakdogan6@gmail.com

Uludağ Üniversitesi Fen-Edebiyat Fakültesi Sosyal Bilimler Dergisi Uludağ University Faculty of Arts and Sciences Journal of Social Sciences Cilt: 20 Sayl: 37 / Volume: 20 Issue: 37 


\section{Positive Attitudes of Low-Status Groups towards High-Status Groups}

\section{ABSTRACT}

The main goal of this study is to compile research findings that explain the attitude of low-status groups towards high status group, conceptualized as out-group favoritism, and to discuss the findings on the basis of self-esteem, efficacy and continuity identity motivations. The research findings gathered within the scope of the study were handled in the context of the Fundamental Correspondence Bias (FCB) and Terror Management Theory (TMT). Findings of studies on the tendency towards FCB show that the reason of the positive attitude of low-status groups toward high status group may be related to the sense of control, which is a basic motivation, and related to anticipating the possible threats from them and being cautious against those threats. Findings of studies examined in the context of TMT show that the reason of low-status groups' supportive attitude towards the system may be related to that the system fulfills various identity motives.

Key words: outgroup favoritism, identity motivation, self-evaluation motivation, fundamental correspondence bias, terror management theory

\section{Giriş}

Sistemi Meşrulaştırma Kuramı (SMK) düşük sosyal statüde bulunan grupların üyelerinin herhangi bir şekilde benliklerinin ilişkili olmadığı yüksek statülü gruplara yönelik belirli durumlarda tarafgirlik sergileyerek onları benliğinin bir parçası olan iç gruptan üstün tuttuklarını ve iç gruba karşı kayırdıklarını öne sürmektedir (Jost 2001: 184). Bu kuram üzerinde çalışan araştırmacılar bunun sebebinin düşük sosyal konumlu grupların üyelerinin iç gruba yönelik olumsuz kalıpyargıları ve üst konumlu grupların avantajlı konumunun devamını sağlayan (dış grupla ilgili) olumlu kalıpyargıları içselleştirmeleri olduğunu öne sürmektedirler (Jost vd. 2002: 120). Bu araştırmacılara göre düşük statülü grup üyeleri sistemi suçlamak yerine kötü konumlarından dolayı kendilerini suçlamayarak sistemi meşrulaştırmaktadırlar (Jost ve Banaji 1994). Kurama göre sistem içinde dezavantajlı konumda olan bu kişilerin sistemi meşrulaştırma 
eğilimi onların deneyimlediği gerginlik ve adaletsizlik benzeri olumsuz duygu durumunu hafiflemektedir (Jost vd. 2002).

Düşük statülü grupların üyelerinin yüksek statülü gruplara yönelik söz konusu tutumuna ilişkin SMK'nın yukarıda sunulan varsayım ve açıklamaları ana akım psikolojinin insan doğasına ilişkin açıklamalarıyla pek uyuşmamaktadır. İnsanların önemli bir kısmı kendini ve benliğinin bir uzantısı olan grubunu olumlu bir algıda görme ve kayırma güdüsünün etkisi altındadır (Hogg vd. 2011: 120). Hatta yapılan araştırmalara göre kişinin benliğini olumsuz algılaması ve kendini diğerlerinden aşağı bir konumda görmesi öz saygıyı zedelemekte, benliği duygusal olarak zorlamakta ve sorunlara neden olmaktadır (Baumeister 1998: 694). Ancak statü farklılıklarının söz konusu olduğu belirli koşullarda yapılan birçok çalışmadan edinilen bulgular düşük statülü grupların üyelerinin yapılan gruplar arası çeşitli değerlendirmelerde yüksek statülü grupları iç gruptan daha olumlu değerlendirdiğini göstermektedir (Batalha vd. 2007; Jost 2001; Jost vd. 2000). Peki, bu bulgular SMK'nın öne sürdügü gibi gerçekten dış grup tarafgirliğini mi gösterir, yoksa bu "beklenmedik" bulguların farklı açıklamaları olabilir mi?

Vignoles ve arkadaşlarının yaptıkları literatür incelemesi sonucunda bir kimlik sahibi olma ihtiyacının altında yatan ve kişinin grupla bağını kuran ve gruplar arası davranışı yönlendirme potansiyeli olan altı farklı motivasyonu belirlemişlerdir. Bunlardan ikisi yaygın bir şekilde incelenen pozitif ayırt edicilik ve özsaygı iken; diğer dördü gruplar arası ayırt edicilik (kayırma) ile ilgili yapılan çalışmalarda çok fazla incelenmeyen kontrol algısı, süreklilik algısı, yaşamın anlamı ve ait olma şeklinde kavramlaştırılmış motivasyonlardır (Vignoles vd. 2002: 203). SMK'cıların dış grup tarafgirliği şeklinde yorumladığı düşük statülü grupların üyelerinin söz konusu tutumuyla ilgili edinilenbulgulara yukarıda bahsedilen özsaygı, süreklilik algısı ve kontrol algıs1 kimlik motivasyonları temelinde alternatif bir açıklama üretmek mümkün gibi görünmektedir. $\mathrm{Bu}$ araştırmanın temel amacı "dış grup 
tarafgirliğine" SMK'dan farklı açıklama getiren çalışma bulgularını derlemek ve özsayg1, kontrol algısı ve süreklilik motivasyonları temelinde tartışmaktır (sadece bu üç motivasyonun incelenme sebebi konuyla ilgili derlenen bulguların belirgin olarak bu üç motivasyonu yansıttığı gözlenmesidir). $\mathrm{Bu}$ amaç doğrultusunda; davranış1 açıklamada özsaygı, kontrol algısı ve süreklilik motivasyonlarına vurgu yapan, bu motivasyonları merkeze alan Temel Uyuşma Yanlılı̆̆ ve Terör Yönetimi Kuramı literatürleri incelenmiş ve kişilerin kendisinden yüksek statüde olan insanlara yönelik tutumunu ele alan çalışma bulguları derlenmiştir.

\section{Temel Atıf Hatası (Temel Uyuşma Yanlılığı)}

Temel atıf hatası belirli bir davranışa sebep olabilecek belirgin çevresel faktörlerin bulunduğu durumlarda bile davranışın kişisel içsel özellikler üzerinden açıklanması eğilimidir (Ross 1977: 184). Gilbert ve Malone insanlardaki bu eğilim için; bir kişi tarafından sergilenen davranışın onun kişiliğiyle (içsel özellikleriyle) uyuştuğu anlamına gelen "uyuşma yanlılığı" (correspondence bias) kavramının kullanılmasını önermişlerdir (Gilbert ve Malone 1995: 32). Çünkü araştırmacılar bunu bir hata olarak değil bilgi işleme süreci açısından kaynak ve zaman tasarrufu sağlayan bilişsel bir yanlılık (kestirme) olarak ele alınması gerektiğini vurgulamaktadır (Nisbett vd. 1980: 463). Normal koşullarda davranışın nedenini doğru belirlemek için davranışın hangi faktörlerle birlikte değiştiğini analiz edip tutarlılık, belirginlik ve benzerlik bilgisine dayanarak nedensel açıklama yapmak gerekmektedir (Kelley 1973). Ancak bu tür bir yükleme çok sayıda gözlem yapmayı, geniş miktarda durumsal nedenle ilgili bilgiyi bellekte temsil etmeyi, bunları doğru şekilde hatırlamayı ve daha pek çok kaynak ve beceriyi gerekli kılmaktadır (Hogg vd. 2011: 109). Bu yüzden davranışın sebebini bulmada bilişsel bir kestirme olarak uyuşma yanlılığ mekanizmasını kullanmak bilişsel kısıtlılığının üstesinden gelmeyi sağlamakta ve belirsizlik durumunda karar almayı kolaylaştırmaktadır. 
Çevremizdeki insanların sergilediği davranışların sebebini anlamak ve açıklamak onların sadece ne şekilde davranacaklarını tahmin etmemizi kolaylaştırmakla kalmaz aynı zamanda onların davranışı üzerinde etkili olmamıza ve onları denetlememize imkân da vermektedir (Försterling vd. 1988: 231-232). Bu anlamda yükleme yapmamızın temelinde çevremiz üzerinde bir kontrol algısı oluşturma ihtiyacı yatmaktadır. Wallston ve arkadaşları (1987: 5) kontrol kavramını, "kişinin kendi içsel durumunu ve davranışlarını belirleyebileceğine, çevresini etkileyebileceğine ve istenilen sonuçlara ulaşabileceğine dair sahip olduğu inanç" olarak tanımlamıştır. Klinik alanında yapılan çalışmalara göre kişinin kendi hayatı üzerinde sahip olması gereken kontrol duygusunun yokluğu strese sebep olarak kişinin özsaygıs1 üzerinde doğrudan negatif bir etki yaratmaktadır (Wallston vd. 1987).

\section{Uyuşma Yanlılığı İle İlgili Araştırma Bulguları}

İnsanlar kendi kaderini kontrol ettiklerine inanma konusunda temel bir ihtiyaca sahip olduklarından içinde bulundukları durumların nedenini dışsal faktörlerde değil içsel özelliklerde arama eğilimindedirler. Yapılan bazı çalışmalarda kendi performansları konusundaki değerlendirmelerde haksızlığa uğradıklarına ilişkin ortada açık deliller olduğu durumlarda dahi insanların kendi başarısızlıklarını içsel özelliklerine atfettikleri görülmüş̧ür. Örneğin Ruggiero vd. (1997: 385-386) tarafından biri kadınlarla diğeri Asya / Afrika kökenli Amerikalılarla yapılan iki farklı çalışmada; dört farklı koşuldaki katılımcılardan işe alınmak için girdikleri mülakattaki başarısızlıkları konusunda nedensel açıklama üretmeleri istenmiştir. Bu koşulların üçünde katılımcılara jüri üyelerinin belli bir oranının (\% 25, \% 50, \% 75) kendilerine ayrımcılık yaptıkları bilgisi verilmiştir. Çalışma sonucuna göre, jüri üyelerinin dörtte biri ayrımcılık yapt1, yarıs1 ayrımcılık yaptı ve dörtte üçü ayrımcılık yaptı bilgisinin verildiği üç farklı koşulda katılımcılar kötü sonuç için içsel atıf yaparak başarısızlıklarının sorumluluğunu üstlenmişlerdir. Katılımcılar sadece 
jüri üyelerinin tamamının kendi performansını haksız yere kötü değerlendirdiği bilgisinin verildiği koşulda başarısızlığı konusunda dışsal atıf yapıp bu sonucu hak etmediklerini ifade ederek duruma itiraz etmişlerdir. Araştırmanın diğer önemli bir bulgusu da elde ettiği kötü sonucu jüri üyelerinin önyargılı tutumuna atfeden katılımcılara kıyasla içsel atıf yaparak başarısızlığın sorumluluğunu alan katılımcıların özsaygı düzeyinin anlamlı şekilde daha yüksek çıktı̆̆ı yönündedir. Araştırmacılar bu bulguyu yorumlamada kendi durumu üzerindeki kontrol duygusunun önemine vurgu yapmışlardır. $\mathrm{Bu}$ da kontrol algısının özsaygıyla yakından ilişkili olduğunu kontrol algısı güçlendikçe özsaygının buna bağlı olarak arttı̆̆ını göstermektedir. Aynı iki araştırmacı tarafından daha önce benzer bir çalışma deseni kullanılarak kadınlarla gerçekleştirilen bir çalışmada benzer bulgular elde edilmiştir (Ruggiero vd. 1995: 826).

Moradi ve Hasan (2004: 424) Amerika'da yaşayan Arap kökenli vatandaşlara yönelik 11 Eylül saldırısından sonra artan önyargı ve ayrımcılığa kendilerinin nasıl bir yükleme yaptıklarını (algılanan kontrol düzeyi) ve bunun özsaygıları üzerindeki etkisini inceleyen bir çalışma hazırladılar. Araştırmanın sonucuna göre maruz kaldığı kötü muameleye dışsal (beyazların önyargılı tutumuna) atıf yapan katılımcılarda özsaygı ile algılanan ayrımcılık düzeyi arasında negatif bir ilişki (-.10) varken; içsel atıf yapanlarda bu ilişkinin pozitif (.66) olduğu görülmüştür. Araştırmacılar içsel atıf yapanların özsaygısındaki bu olumlu farkı algılanan kontrolün rolüne bağlamışlardır. Algılanan kontrolün özsayg1 ve benlik üzerindeki olumlu etkisini vurgulayan bu görüşü destekleyen çok sayıda çalışma bulguları literatürde mevcuttur. Örneğin Ruggiero ve Major (1998: 835) ayrımcılığın sebep olduğu yönünde güçlü kanıtların olduğu zamanlarda bile düşük statülü grupların elde ettiği başarısızlı̆̆ kendi içsel özelliklerine atfetme şeklindeki düşünme eğilimini ve bunun statü farkından nasıl etkilendiğini incelemek amacıyla yaptığı bir dizi çalışmadan edinilen bulgular bu görüşü doğrulamaktadır. Bu çalışmalardan biri kadın / 
erkek, biri Siyah / Beyaz ve biri laboratuvar ortamında oluşturulan düşük / yüksek statülü yapay gruplarla gerçekleştirilmiştir. Üç çalışmanın ortak sonucuna göre kişinin sergilediği performansa verilen geribildirimde belli bir oranda ayrımcılığın yapıldığı bilgisi kendilerine verilmesine rağmen; düşük statülü grupların üyeleri (yüksek statülü grupların üyelerine kıyasla) anlamlı düzeyde daha fazla içsel atıf yaparak başarısızlığının nedenini verdiği cevapların ve gösterdiği çabanın yetersizliğine bağlamışlardır. Araştırmacılar; düşük ve yüksek statülü grupların başarısızlığı konusunda yaptıkları bu yükleme farklılı̆̆ın olası nedenlerinden birinin ayrımcılığa (dışsal) atıf yapmanın iki grup için farklı psikolojik sonuçlar doğurması olduğunu öne sürmüşlerdir. Düşük statülü gruplar (yüksek statülü gruplara kıyasla) kötü performansının nedenini jürinin ayrımcı tutumuna yüklediğinde kontrol algısı ve özsaygı düzeyinde daha fazla düşüş görülmektedir (Ruggiero vd. 1998: 836). Bu çalışmayı yapan araştırmacıların değinmediği, değişik statüdeki gruplar arasındaki söz konusu farklılığa neden olabilecek diğer olası bir durum da dezavantajlı grupların üyelerinin özsaygısını ve kontrol algısını zedeleyen "kalıp yargl tehdidine" maruz kalmaktan kaçınmayla ilgili olabileceği akla gelmektedir. Kişinin elde ettiği olumsuz sonucun sorumluluğunu diş grubun ayrımcı tutumuna atfetmesi beraberinde kalıp yargi tehdidine maruz kalmayı getirecektir. Dolayısıyla kişi elde ettiği olumsuz sonucun nedensel açıklamasını yaparken -kalıpyargı tehdidine maruz kalmaktan kaçınmak için- üst grubun ayrımcı tutumuna atıf yapmaktan kaçınıyor olabilir. Yapılan bazı çalışmalar yoğun (pervasive) ayrımcılığa yapılan dışsal atıfla seyrek (rare) ayrımcılığa yapılan dışsal atfın dezavantajlı grupların üyeleri için özsaygı ve iyi oluş hali açısından farklı sonuçlarının olduğunu göstermektedir. Örneğin Schmitt ve arkadaşları (2003: 308) tarafından yapılan bir çalışmada elde edilen olumsuz sonucun sebebini açıklama konusunda yoğun cinsiyetçi tutuma atıf yapan kadınların cinsiyetçilikle ilgili olmayan dışsal faktöre (ya da seyrek cinsiyetçiliğe) atıf yapanlara kıyasla özsaygı düzeyi daha düşük çıkmış ve daha olumsuz duygular rapor etmişlerdir.

Uludağ Üniversitesi Fen-Edebiyat Fakültesi Sosyal Bilimler Dergisi Uludağ University Faculty of Arts and Sciences Journal of Social Sciences Cilt: 20 Sayı: $37 /$ Volume: 20 Issue: 37 
Yukarıda kontrol kavramını açıklamada da bahsedildiği gibi kontrol algısının kişiye kazandırdığı önemli şeylerden biri "istenilen sonuçlara ulaşılabileceğine dair inançtır". Yoksullukla ilgili yapılan çalışmalarda yoksulların içinde bulunduğu yoksulluğu şans, kader ya da diğer grupların baskısı gibi dış çevresel koşullar yerine yeteri kadar azimli olmama, tembellik gibi içsel özelliklerine atfettikleri yönündeki bulgular bu algı ve inançla ilgili gibi görünmektedir (Feather 1974). Bunun önemli bir sebebi düşük statülü grupların sahip oldukları kötü konumu hak ettiklerine, bundan daha iyisini elde edemeyeceklerine (bu anlamda yetersiz olduklarına), bunun onların kaderi olduğu yönündeki bir inançtan çok; kendi kaderini tayin edebilecekleri ve hak ettikleri konuma ulaşacakları konusunda duydukları bir inanca işaret ediyor gibi görünmektedir. $\mathrm{Bu}$ bağlamda düşünüldügünde "kişisel adil dünya inancl" da kontrol motivasyonuyla yakından ilişkilidir. Kişiye kendi hayatı üzerinde ihtiyaç duyduğu kontrol duygusunu sağlayarak istediklerini elde edebileceği konusundaki güvenini pekiştiren bu inanca sahip insanlar; hayatının daha az tesadüfi ve daha öngörülebilir olduğuna, çalışkan / azimli olanların ödüllendirileceğine ve herhangi bir haksızlık durumunda hakkını eninde sonunda muhakkak alacağına inanmaktadırlar (Kılınç vd. 2011). Yapılan çalışmalar bireysel adil dünya inancının yüksek özsaygı ve psikolojik iyi oluş halini güçlü şekilde yordadığını göstermektedir (Dalbert 1999: 87-88). Begue (2005: 73) tarafından yapılan bir araştırmada kişisel adil dünya inancının yeterlilik / kontrol algısıyla güçlü şekilde pozitif ilişki sergilediği ve yeterlilik / kontrol algısının olumsuz sosyal karşılaştırma durumlarında özsaygının sürdürülmesine hizmet ettiği bulunmuştur.

Bazı araştırmacılara göre insanların temel uyuşma yanlılığı sergilemesi için önemli evrimsel sebepler bulunmaktadır (Andrews 2001: 13). Evrimsel bir perspektiften bakıldığında özellikle insanların kendilerinden (grubundan) güçlü olan ve kendileri için tehdit oluşturan rakiplerinin içsel durumunu anlamaya yönelik atıflar yapma ve temsiller oluşturmanın hayati önemi bulunmaktadır. Onları yenme potansiyeline 
sahip rakipleri (düşmanları) iyi tartmadan onlarla kavgaya girmenin büyük riskleri bulunmaktadır. Bunun için rakiplerinin nasıl olduğunu tanıma, güçlü ve zayıf yanlarını belirleme konusunda doğru bilişsel bir değerlendirme yapıp ona nasıl bir tepki göstermesi (kaçmalı mı yoksa savaşmalı mı?) gerektiğini belirlemek çok önemlidir (Cosmides vd. 1992: 220). Bilişe evrimsel bakış açısı ile yaklaşan psikologlar; uyuşma yanlılığını hileleri saptamaya ve belirli özellikteki insanların ne şekilde davranacağını öngörmeye yönelik doğuştan gelen, evrimsel kökeni çok eskilere dayandığ 1 için önemli ölçüde otomatikleşmiş olan bir bilişsel eğilim olarak değerlendirmektedir (Andrews 2001: 11).

Atıflar diğer insanların içsel durumunun kişideki zihinsel bir temsilini oluşturmaktadır (Andrews 2001: 15). Diğer insanların zihinsel durumunu doğrudan gözlemleyemediğimizden onu davranış ipuçlarından hareketle anlamaya çalışırız. Yani kişinin niyet, plan ve isteklerini davranış sonuçları üzerinden çıkarsamaya çalışırız (Fein 1996). Bu anlamda uyuşma yanlılığı; ilgili davranışların grupların (ya da bireylerin) kalıcı içsel özelliklerinin bir yansıması olduğunu öne süren Özcülük (essentialism) yanlılı̆̆ıyla da ilişkilidir (Haslam vd. 2000: 123). Aktörün her türlü davranışsal ipucunu onun ilgili kişisel özelliğine atfetmek onun nasıl biri olduğu ve belirli durumlarda ona ne şekilde yaklaşmamız gerektiğini belirlememiz açısından önemlidir.

McPherson ve Young'in (2004: 365) sinif ortaminda öğretmenlerin sinirlenip kızdıklarında öğrencilerin ne tür bir atıf yaptıklarını inceledikleri çalışmasında; öğretmenlerin (dışarıya yansıttığı) öfke düzeyi arttıkça öğrencilerin daha fazla içsel atıf yaptığı görülmüsstür. Öğrencilere görüntüleri gösterilen öğretmenin rol icab1 öfkelendiği bilgisi verilmesine ve koşulların etkisi vurgulanmasına rağmen öğrenciler yine de onu kişiliğiyle ilişkilendirerek içsel atıf yapmayı tercih etmişlerdir. Ross ve arkadaşları tarafından gerçekleştirilen benzer bir çalışmada verilmiş (zorunlu) rollere uygun davranışlarla ilgili nedensel çıkarımda bulunurken insanların ne şekilde açıklamalar ürettiği incelenmiştir. Verilen mülakat görevinde(rastgele 
atanmış) katılımcılardan biri genel kültür (sinema, edebiyat, popüler bilim, psikoloji gibi) alanda hazırlanmış soruları diğer kişiye yöneltmiştir. Diğer katılımcı da bu sorulara cevaplar vermeye çalışmıştır. Araştırma sonuçları hem soru soran ve cevap veren iki katılımcının hem de onları gözlemleyen katılımcıların soru soran kişiyi daha kültürlü, bilgili, becerikli ve zeki buldukları ve sorduğu alana hâkim oldukları yönünde değerlendirme yaparak içsel atıf yapmışlardır (Ross vd. 1977: 491-2). Bu çalışmayı inceleyen Jouffre ve arkadaş1 (2016: 628) benzer bir çalışma yapmış ve tekrarlayan bulgular elde etmiştir. Atıflarla ilgili gerçekleştirilen diğer bir araştırmada bazı öğrencilere Fidel Castro'yu destekleyen bazılarına da ona karşıt fikirleri içeren metinler okutulmuş ve daha sonra diğer öğrenci arkadaşlarına metinleri okuyan bu öğrencilerin Castro hakkında ne tür (olumlu / olumsuz) bir tutuma sahip oldukları yönünde bir çıkarımda bulunmaları istenmiştir. Değerlendirme yapan katılımcılar öğrenci arkadaşlarının okuduğu metinlerin başkaları tarafından yazıldığını (ve rastgele onlara okutulduğunu) bilmelerine rağmen Castro lehinde metni okuyanın Castro'yu desteklediği, aleyhindeki metni okuyanın da ona karşıt fikirlere sahip olduğu yönünde değerlendirme yaparak içsel atıfta bulunmuşlardır (John vd. 1967).

Yapılan çalışmalara göre düşük statülü gruplar baskın grupların hem başarılarını hem de başarısızlıklarını onların kalıcı içsel özelliklere atfetmektedir. Örneğin İngiltere'de farklı ideolojiden insanların zenginlikle ilgili yaptıkları nedensel açıklamaları inceleyen bir araştırmaya göre hem muhafazakârlar hem de sol görüşlü insanlar zenginliği kalıcı, içsel özelliklerle ilişkilendirmektedir. Ancak muhafazakârlar zenginliği azim, çalışkanlık, tutumluluk gibi olumlu bireysel özellikler üzerinden açıklarken; sol dünya görüşlü olanlar daha çok bencillik, merhametsizlik dürüst olmama gibi olumsuz içsel özelliklere atıfta bulunmuşlardır (Furnham 1983: 39). Üst grubun başarıları hakkında yapılan bu içsel atıflar (merhametsiz, bencil) bir 
anlamda onlarla ne tür bir ilişki geliştirebilecekleri konusunda da (kalıpyargılar olarak) yol gösterici bir özellik taşır.

Evrimsel bakış açısına göre diğerlerinin davranışları konusunda her zaman otomatik bir şekilde içsel atıf yapmak işlevsel değildir. Bu eğilimin riskleri vardır ve bizi zararlı hatalara düşürebilir. Çünkü diğerleri belli bir yarar elde etmek için bize karşı; içsel durumu (niyet, istek, plan) konusunda yanıltıcı şekilde davranabilir. Diğerlerinin içsel durumunu (davranışsal ipuçlarından hareketle) tahmin etmede bizim için maliyeti büyük olacak bir hataya düşebiliriz. Kişinin kötü niyet ve planları varken yanıltıcı şekilde iyi davranışlar sergileyebilir ve bize karşı kötü emelleri olan birini (davranışlarından hareketle) iyi olarak değerlendirip zararlı bir alışverişe girebiliriz (Hilton vd. 1993). Bu hataya düşmemek için Gilbert'e (1993) göre davranışa yükleme yaparken ikili (iki basamaklı) bir süreçten geçeriz. Birinci süreç otomatik, hızlı, kendiliğinden gerçekleşen ve niyetli olarak bastırılması mümkün olmayan bir süreçken; ikinci süreç, kontrollü, niyetli olarak başlatılır ve değiştirilebilmektedir. Araştırmacıya göre ilk olarak diğerlerinin tüm davranışları konusunda öncelikle içsel atıf yaparak uyuşan yanlılık sergileriz. Ancak eğer onun niyetinden kuşkulanırsak ya da başka motivasyonlarımız varsa daha fazla düşünür ve duruma bağlı olası dışsal nedenleri hesaba katıp son yüklemeyi yeniden yaparız (akt, Aronson vd. 2012: 217). Yapılan çalışmalar söz konusu evrimsel görüşü desteklemektedir. $\mathrm{Bu}$ çalışmalar insanların kandırılmaya karş1 çok duyarlı oldukları, bu konuda özel gayretlerinin olduğunu ve diğerlerinin iyi niyetinden kuşku duyduğunda daha az uyuşma yanlılığ sergilediği ve ikinci süreci başlatarak durumsal faktörleri de değerlendirip yeni bir yükleme yaptıklarını göstermektedir (ör. Fein vd. 1990: 764; Hilton vd. 1993; Fein 1996: 1180). Ayrica yapılan çalışmalar insanların doğru değerlendirme yapma konusunda çıkarlarının (menfaatlerinin) olduğu durumlarda uyuşma yanlılığını esneterek ikinci süreci devreye sokup ilgili sosyal bilgiyi işledikten sonra atıf yaptıkları yönünde bulgular elde edilmiştir (Vonk 1999).

Uludağ Üniversitesi Fen-Edebiyat Fakültesi Sosyal Bilimler Dergisi Uludağ University Faculty of Arts and Sciences Journal of Social Sciences

Cilt: 20 Sayı: $37 /$ Volume: 20 Issue: 37 
Özetle yukarıda temel uyuşma yanlılığı bağlamında ele alınan açıklamalara ve çalışma bulgularına dayanarak düşük statülü grupların üyelerinin kendi grubuna ve üst statülü gruplara yönelik tutumuyla ilgili iki açıklama üretmek mümkün görünmektedir. Birincisi; düşük statülü grupların içinde bulundukları kötü konumun nedenini kendilerinde aramaların sebebi kendilerini değersiz, yetersiz ya da daha iyi bir konuma layık görmemekle değil (kendi kaderi üzerinde) ihtiyaç duydukları kontrol algısı ile ilişkili gibi görünmektedir. Kişinin kendi durumunu belirleyebileceğine ve istenilen sonuçlara ulaşabileceğine dair sahip olduğu bu algı (inanç) özsaygı ve kendine güven ile güçlü şekilde ilişkilidir. İkincisi; dezavantajlı grupların yüksek statülü (baskın) grupların yetkinliğini kabul etmesi ve başarılarını onların içsel özelliklerine atfetmesinin sebebi onlara karşı duyulan bir sempatiden çok onların nasıl insanlar olduklarını anlamaya çalışma, kendilerine tehdit oluşturacak güçlü yanlarını tespit etme ve onlara karşı tedbirli olma ihtiyacıyla ilgili olabilir. Bu da benzer bir şekilde kontrol algısıyla ilgilidir, çünkü kişinin diğerlerinin davranışını ön görebilmesi ve bu davranışlara etki edebilmesi için davranışlarının kaynağını belirlemesi ve bu konuda içsel ya da dışsal bir algı oluşturması gerekmektedir.

\section{Terör Yönetimi Kuramı}

Terör Yönetimi Kuramına göre toplumdaki tüm grupların içinde yaşadığı (gerçekliğe dair ortak sembolik algılardan oluşan) kurulu düzen, insanlarda varlıklarını düzenli, anlamlı, güvenli ve sürekliliği olan bir gerçeklik içinde sürdürdüğü algısını oluşturmaktadır (Pyszczynski vd. 2004: 464). Kuram, insanların kurulu düzene sarıldıkça ve bu düzenin sağladığı değerlere uygun şekilde yaşadıkça benlik saygılarının arttığını, kazanılan benlik saygısının da ölüm korkusuna karş1 bir koruyucu işlev gördügünü öne sürmektedir (Greenberg vd. 1986: 189).

Kişilere bağlanma ve kendini onun parçası olarak görüp güvende hissetme olanağı sağlayan bu sosyal yapılar insanlar tarafından 
kişiselleştirilmektedir. İnsanlar kişiselleştirdiği kültürel değerlere ve bu değerlere dayanan standartlara uygun olarak yaşadığı sürece kendini değerli ve saygın görmektedir. Ancak kendi değerleri ve ana akım kültürel değerler arasında bir uyumsuzluk yaşayan insanlar "Kültürel Yabancılaşma" duygusunu yaşamaktadırlar (Cozzarelli vd. 1998: 255). İnsanların kendini içinde bulunduğu ana akım kültürden (kurulu düzenin dayandığ 1 değerlerden) farklı görmeleri benlikleri hakkında belirsizliğe, güvensizliğe ve psikososyal sorunlara neden olabilmektedir (Cozzarelli vd. 1998: 254). İçinde yaşanılan baskın kültürden izole olmanın benlik algısı üzerinde böylesine olumsuz sonuçlar doğurması; kim olduğumuzun (benliğimizin) içinde yaşadığımız kültürle ilişkisini ve kültürel dünya görüşünün benliği koruyucu ve destekleyici işlevini yansitmaktadir.

\section{Kültürel Yabancılaşma İle İlgili Araştırma Bulguları}

Kültürel yabancılaşma bireyin benlik değerlendirmesi üzerinden psikolojik uyumunu etkilemektedir. Cozzarelli vd. (1998: 265) tarafından yapılan çalışmaya göre kültürel yabancılaşma algısı yüksek olan kişiler daha düşük düzeyde özsayg1 ve daha yüksek düzeyde kayg1 rapor etmişlerdir. Çalışma sonuçlarına göre kültürel yabancılaşmanın kişi üzerindeki (düşük özsaygı, kaygı, yaşam tatminsizliği gibi) olumsuz psikolojik sonuçları etkisini benlikte yaşanan uyumsuzluk (self-discrepancy) algıs1 üzerinden göstermektedir (Cozzarelli vd. 1998: 255). Bernard ve arkadaşları (2006: 88) yaptıkları bir çalışmada kültürel yabancılaşmanın en güçlü göstergelerinden birinin kişinin benimsediği kültürel değerler ile ana akım kültürel değerler arasındaki uyumsuzluk olduğunu ortaya koymuşlardır. Kişinin sahip olduğu değerler ve sosyopolitik tutumu ile toplumun çoğunluğunun benimsedikleri arasında algılanan uyumsuzluk düzeyi arttıkça katılımcıların rapor ettiği kültürel yabancılaşma düzeyi artmıştır. Kohn vd. (1983) tarafından yapılan bir çalışmada da benzer bulgular elde edilmiştir. 
Yukarıda referans verilen çalışma bulgularının da gösterdiği gibi kişinin ya da grubun kendini bu yapıdan farklılaştırması kültürel yabancılaşmaya neden olmaktadır. Bu da özsaygıyı zedelemekte ve yaşam tatminsizliğine neden olmaktadır. Yani belirli durumlarda üyelerin grubunu ana akım (çoğunlukta olan baskın) kültürden farklılaştırması özsaygı kazandırmak yerine zararlı sonuçlar doğurmaktadır. Dolayısıyla azınlık grupların üyelerinin kendi iç grubunu ana akım kültürden ve toplumdaki baskın gruptan farklılaştırmamasının ve bu baskın grubun lehine olan sistemi desteklemesinin önemli sebeplerinden biri kültürel yabancılaşma hissinden kaçınmakla ilgili olabilir.

\section{Özsaygı İle İlgili Araştırma Bulguları}

Yapılan çalışmalarda insanlara ölümlü oldukları hatırlatıldığı durumlarda ihtiyaç duydukları özsaygıyı elde etmek için kültürel dünya görüşlerine daha sıkı sarıldıkları ve onu savunanlara karşı daha olumlu tutumlar geliştirdiği yönünde güvenilir bulgular elde edilmiştir (Dechesne vd. 2003: 730; Arndt vd. 1996: 384; Greenberg vd. 1990: 317).

Arndt ve Greenberg'in (1999: 1335) gerçekleştirdiği çalışma sonucuna göre özsaygısı düşük olan kişiler ölüm belirginliğinin ön plana çıkarıldığı (ölümle ilgili düşünceleri zihinlerinde canlandırdıkları) koşulda ihtiyaç duyduğu öz saygıyı elde etmek için kültürel dünya görüşlerine daha sıkı sarılmışlar ve buna tehdit oluşturan kişilere yönelik daha sert tepkiler vermişlerdir. Benzer şekilde Rosenblatt ve arkadaşlarının (1989: 684) yaptığı çalışmaya göre katılımcıların benlik saygısının tehdit edildiği (ölümlü olduklarının hatırlatılması gibi) durumlarda kültürel dünya görüşlerini destekleyen (koruyan) kişilere yönelik daha olumlu tutumlar geliştirmişlerdir. Harmon-Jones ve arkadaşlarının (1997: 33) özsaygı düzeyinin kültürel dünya görüşünü savunmayla ne tür bir ilişkisi olduğunu incelemek amaciyla gerçekleştirdiği iki araştırmanın sonucuna göre özsayg1 düzeyi 
(manipüle edilerek) düşürülen katılımcıların kültürel dünya görüşünü destekleme düzeyi artarken, öz sayg1 düzeyi yükseltilenlerde destekleme düzeyinde bir düşüş olduğu görülmüştür.

Nail vd. (2009: 235-236) Amerika'da gerçekleşen 11 Eylül saldırısının ABD vatandaşlarının politik yönelimi üzerinde ne tür bir etkisi olduğunu inceledikleri bir çalışma sonucuna göre saldırı sonrasinda hem muhafazakârlarda hem de liberal partiyi destekleyenlerde ciddi bir muhafazakârlaşma olduğu yönünde bulgular elde edilmiştir. Hem muhafazakâr hem de liberal görüşlü vatandaşlar başkan Bush'u, politikalarını ve yapılan askeri harcamalardaki artışı (saldırı öncesine kıyasla) daha fazla desteklemişlerdir. Willer (2004: 9) gerçekleştirdiği bir arşiv çalışmasında Amerika'da 2001 ile 2004 yıılları arasında devlet yetkilileri tarafından verilen terör uyarılarının (alarmın) vatandaşların başkan Bush'u desteklemelerini ne şekilde etkilediğini (kamuoyu anket araştırmaları üzerinden) incelemiştir. Çalışmanın bulgularına göre verilen terör alarmı ile başkan Bush'un desteklenme düzeyi arasında güçlü pozitif bir ilişki görülmüştür. İnsanların normalde desteklemediği başat (muhafazakâr) kültürel dünya görüşünü belirsizlik ve tehdit durumunda desteklemeye yönelmesi ile ilgili bu bulgular, mevcut sistem karşında kısmen zayıf (ekonomik, politik, sosyal) konumda olan kimlik mensuplarının baskın kimlikten yana tutum sergilemesinin belirli kaygı ve motivasyonlarla ilişkisini ortaya koymaktadır. Belirsizliğin baskın olduğu, işlerin kontrolden çıktığ algısının yerleştiği ve can güvenliğinin azaldığı durumlarda insanlarda benlik saygısı zedelenir ve insanlar bunu telafi etmeye motive olur. Terör Yönetim Kuramına göre hâkim kültürel dünya görüşünü desteklemek ve buna tehdit oluşturanlara karşı olumsuz tutum sergilemek öz saygıyı arttırmaktadır. Ayrıca kurama göre hâkim kültürel dünya görüşü bir süreklilik hissi ve kontrol algısı da sağlar. Kişiler kendilerinin aleyhine bir sistem de olsa içinde bulundukları kurulu düzende geleceğe ilişkin daha az belirsizlik yaşamakta ve kendi 
hayatları üzerinde (mevcut kurallar dâhilinde) daha fazla kontrol algısına sahip olduklarına inanmaktadır (Kılınç vd. 2011).

Özetle yapılan çalışmalar incelendiğinde yüksek statülü grubun lehine olan sistemin dezavantajlı gruplar tarafindan desteklenmesinin önemli sebepleri vardır. Yukarıda da bahsedildiği üzere kurulu düzen kişinin yaşamını düzenli (öngörülebilir), sürekliliği olan ve anlamlı bir şekilde algılamasını sağlamaktadır. Bu yapının kişiye sağladığı en önemli şeylerden biri özsaygı diğeri hayatın tahmin ve kontrol edilebilir olduğu hissidir. Gruplar arası bağlamda yapılan çalışmalarda iç grubun kayırılmasının altında zaten bu motivasyonlar yatmaktadır. $\mathrm{Bu}$ motivasyonlar sistem tarafindan tatmin edildiği sürece grubu dezavantajlı konumda bile olsa kişinin bunun devamından yana tutum geliştirmesi SMK'nın iddia ettiği gibi kendi aleyhine (kendini zayıflatan) değil aksine kendini güçlendiren bir eğilim gibi görünmektedir.

\section{Sonuç ve Değerlendirme}

SMK düşük statülü grupların üyelerinin kötü konumlarından dolayı sistemi ya da baskın grupları suçlamak yerine kendilerini suçladıklarını ve bunun içinde bulundukları konumu kabullenmeleriyle ilgili olduğunu öne sürmektedir (Jost ve Burgess 2000: 121). Evrimsel kökü çok eskilere dayandığı düşünülen ve otomatikleştiği konusunda güçlü belirtiler bulunan temel uyuşma yanlılığı (TUY) mekanizmasıyla ilgili yapılan kuramsal ve görgül çalışmalar; dezavantajlı grupların başarısızlıkları konusunda içsel atıf yapma eğiliminin belli bir anlamının ve benliği koruyucu-güdüleyici bir işlevinin olduğunu göstermektedir. Literatürde aksini de gösteren çok miktarda bulgu olmasıyla birlikte bu çalışma kapsamında derlenen bazı bulgular kendi başarısızlıkları konusunda içsel atıf yapanların dışsal atıf (baskın grubun ayrımc1 tutumunu sorumlu tutmak gibi) yapanlara kıyasla özsaygı düzeylerinin daha yüksek olduğu yönündedir (Moradi vd. 2004; Ruggiero vd. 1997). Bu alanda çalışan araştırmacılar davranış1 
anlamada özsaygının yanı sıra özsaygıyla ilişkili olan ve onu güçlendiren bir motivasyon olan kontrol algısının rolünü de incelemektedir. Çalışma sonuçlarına bakıldı ğında dezavantajı grupların içsel atıf yapmasının çok temel bir ihtiyaç olan kontrol algısını güçlendirdiği ve bu algının da özsaygının temelini oluşturduğu anlaşılmaktadır. Ayrıca çalışmalara göre yüksek statülü gruplara kıyasla düşük statülü grupların dışsal atıf yapmasının kendileri için daha olumsuz sonuçları (kaygı, olumsuz duygu durumu gibi) olduğunu ve içsel atıf yapmanın dezavantajlı gruplarda özsaygıyla daha fazla ilişkili olduğunu göstermektedir (Ruggiero vd. 1998). Bulgular değerlendirildiğinde gruplar arasındaki bu farkın kalıp yargı tehdidiyle ilişkili olabileceği akla gelmektedir. Dezavantajlı grupların üyelerinin iç gruba yönelik olumsuz kalıp yargılara göre değerlendirileceklerine veya buna göre muamele göreceklerine dair yaşadıkları yoğun endişe olan (Steele vd. 1995: 797) kalıp yargı tehdidi kişinin kendi davranışları üzerinde sahip olduğu denetim algısını kaybetmesine, dışsal faktörlerin denetimine girmesine ve benlik kaynaklarını tüketmesine neden olabilmektedir. $\mathrm{Bu}$ yüzden bu grupların üyeleri kalıp yargı tehdidine maruz kalmamak için başarısızlıklarını diğerlerinin önyargılı tutumuna atfetmekten kaçınıyor olabilirler.

SMK'nın önemli bir iddiası da dezavantajlı grupların avantajlı grupları kendinden üstün tuttuğu ve onların yüksek sosyal konuma kendilerinden daha fazla layık buldukları yönündedir (Jost vd. 1994: 8). TUY ile ilgili yapılan teorik açıklamalar ve görgül çalışmalar ışığında dezavantajlı grupların bu tutumu değerlendirildiğinde bunun üst statülü gruplara yönelik olumlu bir meyilden ziyade onlardan gelebilecek tehditleri belirleme ve bunlara karşı kendilerini korumayla ilgili olabileceği düşünülmektedir. İnsanlar kimlere güvenip ortaklıklar kurabileceğini ve kimlerin kendileri için tehdit oluşturduğunu anlamak için diğer insanların kim olduğunu ve nasıl davranacaklarını bilme ihtiyacı içerisindedirler. Bunu bilmenin en etkili yollarından biri onların ne tür özelliklere ve eğilimlere sahip olduklarını belirlemektir. TUY 
yaklaşımına göre insanlar birbirinin içsel (niyet, istek, plan, hedef gibi) durumunu doğrudan gözlemleyemediğinden davranışsal sonuçlarından hareketle bunu anlamaya çalışmaktadır. $\mathrm{Bu}$ da belirli davranışların belirli içsel özelliklere tekabül ettiğini ve ondan kaynaklandığını kabul etmekle mümkün olmaktadır (Fein 1996). Dolayısıyla diğer insanları tanıma sürecinde onların sergilediği davranışları ve sahip oldukları şeylerin, bulundukları konumun onların içsel özelliklerinden kaynaklandığını varsaymak işi kolaylaştırmakta ve hızlandırmaktadır. Diğer türlü onları tanımak için davranışlarının ne tür etmenlerle birlikte değiştiğini gözlemek ve tutarlılık-belirginlik-benzerlik bilgisine dayanarak çıkarımda bulunmak gerekecektir. Bu da çok sayıda gözlemi ve uzun bir zamanı gerektirmektedir. Bu çalışma kapsamında temel atıf yanlılığıyla ilgili ele alınan çalışmalarda (Furnham 1983; John vd. 1967; McPherson ve Young 2004; Ross vd. 1977) değerlendirme yapan katılımcıların davranışsal sonuçları -ortada belirgin çevresel faktörlerin etkisi bulunsa bile- aktörlerin içsel özelliklerine atfetmesinin aslında çok kısa bir sürede ve kısıtlı davranışsal ipucundan hareketle onları tanımayla, nasıl insanlar olduğunu belirlemekle ilgili olduğu söylenebilir. Bu bilgi ve bulgular ışı̆̆ında dezavantajlı grup üyelerinin avantajlı grupların sosyal konum gibi başarılarını içsel özelliklerine atfetmesi ile ilgili tutumları değerlendirildiğinde, bunun onları kayırmak anlamına gelmekten çok onların ne tür insanlar olduklarını bilme ve onlar hakkında zihinsel bir temsil oluşturmakla ilgili gibi görünmektedir (Andrews 2001: 15). Evrimsel olarak insanların kendilerinden güçlü olan ve tehdit oluşturan rakiplerinin içsel durumunu anlamaya yönelik atıflar yapma ve temsiller oluşturmanın hayati önemi bulunmaktadır. Atalarımızın grup içerisinde hızlı değişen ortaklık örüntülerini takip edebilmesi, belirli özellikteki insanların (özellikle dışarıdaki rakiplerin) ne şekilde davranacağını kestirebilmesi ve bu sosyal satranç oyunu esnasında hem grup içindeki hem de diğer gruplardaki insanların aldatıcı (hileli) davranışlarını ve olası hamlelerini tahmin etmesi gerekmektedir (Andrews 2001: 12). Doğal seçilimin evrimsel ilkelerine göre uyum değeri yüksek olan temel uyuşma yanlılığı bilişsel yapının 
bir parçası haline gelmiştir (Cosmides vd. 1992: 220). Schachter'a (1971) göre hedef bir kişiye yönelik bizde uyanan duygusal ve fizyolojik uyarılma onunla ilgili yaptığımız nedensel çıkarımlardan (bilişsel değerlendirmeden) sonra oluşmaktadır. Yani bizim hedef bir kişiyi sevip yaklaşma, öfke hissedip saldırma ya da korkup kaçmamızı belirleyen şey onun ne tür özelliklerde biri olduğunu ve içsel durumunun (bize yönelik niyet, istek ve planının) ne olduğunu belirleyen nedensel açıklamalardır. Özetle diğer insanların davranışlarının içsel sebebini (içsel durumunu) anlamak ve açıklamak onların ne şekilde davranacağını öngörmemizi, onlara karşı tedbirli olmamızı ve en etkili davranışı belirlememizi kolaylaştırarak çevremiz üzerinde bir kontrol duygusu oluşturmamızı sağlamaktadır. $\mathrm{Bu}$ da ihtiyaç duyduğumuz özsaygıyı güçlendirmektedir (Forsterling vd. 1988: 231-232). Bu bağlamda dezavantajlı grupların -üst statülü grupların konumla ilgili başarılarını onların içsel özelliklerine atfetme- eğilimi değerlendirildiğinde bunun dış gruba yönelik olumlu bir tutum olmayabileceği kuşkusu güçlenmektedir.

SMK'nın önemli iddialarından biri de dezavantajlı grupların üyelerinin kendi aleyhine ve üst statülü grupların lehine olan durum ve düzenlemelerin devamını sağlayacak şekilde bu durum ve düzenlemeleri algılaması, anlaması ve açıklaması şeklinde bir eğiliminin olduğu yönündedir. TYK bağlamında yapılan çalışmalardan edinilen bulgular dezavantajlı grupların sistemi desteklemelerinin kendi aleyhine olmadığını, bunun onların belirli ihtiyaç ve motivasyonlarını (özsayg1, süreklilik, anlam) tatmin ettiği anlaşılmaktadır. Sistemi destekleme eğiliminin dış grup tarafgirliğiiyle güçlü şekilde pozitif ilişki içinde olduğunu gösteren çalışma bulguları mevcuttur (ör. Jost vd. 2003: 260; Jost vd. 2000: 209). Bunun önemli bir sebebi uzun yıllar boyunca üst statülü grupların sistemi yönetmesi ve dezavantajlı grupların bu üst statülü grubu sistemle özdeşleştirmesi olarak görülebilir.

Uludağ Üniversitesi Fen-Edebiyat Fakültesi Sosyal Bilimler Dergisi Uludağ University Faculty of Arts and Sciences Journal of Social Sciences Cilt: 20 Sayl: 37 / Volume: 20 Issue: 37 


\section{Kaynaklar}

Andrews, Paul W. (2001). "The Psychology of Social Chess and the Evolution of Attribution Mechanisms: Explaining the Fundamental Attribution Error". Evolution and Human Behavior, C. 22, S. 1, s. 1129.

Arndt, Jamie ve Jeff Greenberg (1999). "The Effects of a Self-Esteem Boost and Mortality Salience on Responses to Boost Relevant and Irrelevant Worldview Threats". Personality and Social Psychology Bulletin, C. 25, S. 11, s. 1331-1341.

Arndt, Jamie vd. (1997). "Subliminal Exposure to Death-related Stimuli Increases Defense of the Cultural Worldview". Psychological Science, C. 8, S. 5, s. 379-385.

Batalha, Luisa vd. (2007). "Outgroup Favoritism: The Role of Power Perception, Gender, and Conservatism". Current Research in Social Psychology, C. 13, S. 4, s. 38-49.

Baumeister, Roy F. (1998). "The Self". Advanced Social Psychology: The State of The Science, s. 680-740.

Bègue, Laurent (2005). "Self-Esteem Regulation in Threatening Social Comparison: the Roles of Belief in a Just World and Self-Efficacy". Social Behavior and Personality: An International Journal, C. 33, S. 1, s. 69-76.

Bernard, Mark M. vd. (2006). "Cultural Estrangement: The Role of Personal and Societal Value Discrepancies". Personality and Social Psychology Bulletin, C. 32, S. 1, s. 78-92.

Blaine, Bruce ve Jennifer Crocker (1993). "Self-esteem and Selfserving Biases in Reactions to Positive and Negative Events: An Integrative Review." Self-esteem, s. 55-85. 
Cosmides, Leda ve John Tooby (1992). "Cognitive Adaptations for Social Exchange". The Adapted Mind: Evolutionary Psychology and the Generation of Culture, s. 163-228.

Cozzarelli, Catherine ve Joseph A. Karafa (1998). "Cultural Estrangement and Terror Management Theory". Personality and Social Psychology Bulletin, C. 24, S. 3, s. 253-267.

Dalbert, Claudia (1999). "The World is More Just for Me than Generally: About the Personal Belief in a Just World Scale's Validity". Social Justice Research, C. 12, S. 2, s. 79-98.

Dechesne, Mark vd. (2003). "Literal and Symbolic Immortality: the Effect of Evidence of Literal Immortality on Self-esteem Striving in Response to Mortality Salience". Journal of Personality and Social Psychology, C. 84, S. 4, s. 722-737.

Feather, Norman T. (1974). "Explanations of Poverty in Australian and American Samples: The Person, Society, or Fate?" Australian Journal of Psychology, C. 26, S. 6, s. 199-216.

Fein, Steven (1996). "Effects of Suspicion on Attributional Thinking and the Correspondence Bias". Journal of Personality and Social Psychology, C. 70, S. 6, s. 1164-1184.

Fein, Steven vd. (1990). "Suspicion of Ulterior Motivation and the Correspondence Bias". Journal of Personality and Social Psychology, C. 58, S. 5, s. 753-764.

Försterling, Friedrich ve Udo Rudolph (1988). "Situations, Attributions, and the Evaluation of Reactions". Journal of Personality and Social Psychology, C. 54, S. 2, s. 225-232.

Furnham, Adrian (1982). "Why Are the Poor Always with Us? Explanations for Poverty in Britain". British Journal of Social Psychology, C. 21, S. 4, s. 311-322. 
Furnham, Adrian (1983). "Attitudes toward the Unemployed Receiving Social Security Benefits". Human Relations, C. 36, S. 2, s. 135-149.

Gilbert, Daniel T. ve Patrick S. Malone (1995). "The Correspondence Bias". Psychological Bulletin, C. 117, S. 1, s. 21-38.

Greenberg, Jeff vd. (1986). "The Causes and Consequences of a Need for Self-esteem: A terror management theory." Public self and private self. 189-212.

Harmon-Jones, Eddie vd. (1997). "Terror Management Theory and Self-Esteem: Evidence That Increased Self-Esteem Reduces Mortality Salience Effects". Journal of Personality and Social Psychology Copyright, C. 72, S. 1, s. 24-36.

Haslam, Nick vd. (2000). "Essentialist Beliefs about Social Categories". British Journal of Social Psychology, C. 39, S. 1, s. 113-127.

Hilton, James L. vd. (1993). "Suspicion and Dispositional Inference". Personality and Social Psychology Bulletin, C. 19, S. 5, s. 501-512.

Hogg, Michael A. ve Graham M. Vaughan (2011). Sosyal Psikoloji. çev. İbrahim Yıldız ve Aydın Gelmez, Ankara: Ütopya.

Jost, John T. (2001). "How Status and Power Differences Erode Personal and Social Identities at Work: A System Justification Critique". Social Identity Processes in Organizational Contexts, s. 181196.

Jost, John T. ve Mahzarin R. Banaji (1994). "The Role of Stereotyping in System-justification and the Production of False Consciousness". British Journal of Social Psychology, C. 33, S. 1, s. 127.

Jost, John T. ve Diana Burgess (2000). "Attitudinal Ambivalence and the Conflict between Group and System Justification Motives in Low 
Status Groups". Personality and Social Psychology Bulletin, C. 26, S. 3, s. 293-305.

Jost, John T. ve Orsolya Hunyady (2003). "The Psychology of System Justification and the Palliative Function of Ideology". European Review of Social Psychology, C. 13, S. 1, s. 111-153.

Kelley, Harold H. (1973). "The Processes of Causal Attribution." American psychologist, C. 28, S. 2, s. 107-128.

K1lınç, Sibel ve Fuat Torun (2011). “Adil Dünya İnancı”. Psikiyatride Güncel Yaklaşımlar, C. 3, S. 1, s. 1-14.

McPherson, Mary B. ve Stacy L. Young (2004). "What Students Think When Teachers Get Upset: Fundamental Attribution Error and Student Generated Reasons for Teacher Anger". Communication Quarterly, C. 52, S. 4, s. 357-369.

Moradi, Bonnie ve Nadia Talal Hasan (2004). "Arab American Persons' Reported Experiences of Discrimination and Mental Health: The Mediating Role of Personal Control". Journal of Counseling Psychology, C. 51, S. 4, s. 418-428.

Nail, Paul R. ve Ian McGregor (2009). "Conservative Shift Among Liberals and Conservatives Following 9/11/01". Social Justice Research, C. 22, S. 3, s. 231-240.

Pyszczynski, Tom vd. (2004). "Why do People Need Self-esteem? A Theoretical and Empirical Review." Psychological bulletin, C. 130, S. 3, s. 435-468.

Rosenblatt, Abram vd. (1989). "Evidence for Terror Management Theory: I. The Effects of Mortality Salience on Reactions to Those Who Violate or Uphold Cultural Values". Journal of Personality and Social Psychology, C. 57, S. 4, s. 681-690.

Uludağ Üniversitesi Fen-Edebiyat Fakültesi Sosyal Bilimler Dergisi Uludağ University Faculty of Arts and Sciences Journal of Social Sciences Cilt: 20 Sayl: 37 / Volume: 20 Issue: 37 
Ross, Lee (1977). "The Intuitive Psychologist and His Shortcomings: Distortions in the Attribution Process1." Advances in Experimental Social Psychology, C. 10, s. 173-220.

Ross, Lee D. vd. (1977). "Social Roles, Social Control, and Biases in Social-perception Processes". Journal of Personality and Social Psychology, C. 35, S. 7, s. 485-494.

Ruggiero, Karen M. ve Donald M. Taylor (1997). "Why Minority Group Members Perceive or Do Not Perceive the Discrimination That Confronts Them: The Role of Self-esteem and Perceived Control". Journal of Personality and Social Psychology, C. 72, S. 2, s. 373-389.

Ruggiero, Karen M. ve Donald M. Taylor (1995). "Coping with Discrimination: How Disadvantaged Group Members Perceive the Discrimination that Confronts Them". Journal of Personality and Social Psychology, C. 68, S. 5, s. 826-838.

Ruggiero, Karen M. ve Brenda N. Major (1998). "Group Status and Attributions to Discrimination: Are Low-or High-status Group Members More Likely to Blame Their Failure on Discrimination?". Personality and Social Psychology Bulletin, C. 24, S. 8, s. 821-837.

Schmitt, Michael T. vd. (2003). "Women's Emotional Responses to the Pervasiveness of Gender Discrimination. European Journal of Social Psychology, C. 33, S. 3, s. 297-312.

Vignoles, Vivian L. vd. (2002). "Evaluating Models of Identity Motivation: Self-Esteem is Not the Whole Story". Self and Identity, C. 1, S. 3, s. 201-219.

Vonk, Ross (1999). "Effects of Outcome Dependency on Correspondence Bias". Personality and Social Psychology Bulletin, C. 25, S. 3, s. 382-389.

Uludağ Üniversitesi Fen-Edebiyat Fakültesi Sosyal Bilimler Dergisi Uludağ University Faculty of Arts and Sciences Journal of Social Sciences Cilt: 20 Sayı: $37 /$ Volume: 20 Issue: 37 
Wallston, Kenneth A. vd. (1987). "Perceived Control and Health". Current Psychology, C. 6, S. 1, s. 5-25.

Willer, Robb (2004). "The Effects of Government-issued Terror Warnings on Presidential Approval Ratings". Current Research in Social Psychology, C. 10, S. 1, s. 1-12. 


\section{EXTENDED ABSTRACT}

System Justification Theory (SJT) suggests that members of low-status groups blame themselves for their poor status, instead of blaming the system or dominant groups. It also suggests that this is related to accepting their inability (inferior) and embracing their position in which they are located (Jost and Hunyady 2002: 121). Theoretical and empirical studies on the mechanism of fundamental correspondence bias (FCB), which are believed to be based on evolutionary roots going back a long way and have strong indications of automation, demonstrate that the tendency for disadvantaged groups to make internal attributions about their failures has a specific meaning and a protective and motivating function of self. Findings suggest that those with internal attributions have a higher level of self-esteem than those with external attributions (such as holding the discriminatory attitude of the dominant group responsible) for their own failures (Ruggiero and Taylor 1997; Moradi and Hasan 2004). Researchers working on this field in understanding behavior also examine the role of self-esteem as well as the role of perception of control, a motivation that is related to self-esteem and strengthens it. When the results of the study are examined, it is understood that the internal attributions made by the disadvantaged groups strengthen the sense of control, which is a very basic necessity, and this is also the basis of self-esteem.

An important claim of SJT is that disadvantaged groups see advantaged groups as superior to themselves and find them worthier of the high social status (Jost and Banaji 1994: 8). When attitudes of disadvantaged groups are evaluated in the light of theoretical explanations and empirical studies about FCB, they are thought to be related to detecting the threats posed by high-status groups and protecting themselves against those threats, rather than being related to a positive tendency towards high-status groups. People need to know who other people are and how to behave in order to understand who they can trust and build partnerships with and who threaten them. One of the most effective ways of knowing that is to figure out what characteristics and tendencies they have. According to the FCB approach, people are trying to understand this based on their behavioral consequences, since they cannot directly observe the internal (intention, will, plan, target) state of someone. This is possible by recognizing that certain behaviors correspond to certain internal characteristics and originate from them (Fein 1996). Therefore, it is easier and quicker to assume in the process of recognizing other people that the behavior they exhibit, the things they possess, and the status they have originate from their internal characteristics. Otherwise, in order to recognize them, it will be necessary to observe what factors change their behavior and to make inferences based on the knowledge of consistency-specificity-similarity. This requires a lot of observations and a long time.

Uludağ Üniversitesi Fen-Edebiyat Fakültesi Sosyal Bilimler Dergisi Uludağ University Faculty of Arts and Sciences Journal of Social Sciences

Cilt: 20 Sayl: 37 / Volume: 20 Issue: 37 
In the studies examined in terms of the fundamental attribution bias within this study (McPherson et al. 2004; Ross et al. 1977; John et al. 1967; Furnham 1983), participants making assessments attributed behavioral consequences to internal characteristics of actors - even if there were significant environmental factors. It can be said that this is related to determining how people are, in a very short period of time, and by recognizing them with limited behavioral cues. In the light of this information and findings, when the attitudes of disadvantaged group members to attribute successes of advantageous groups such as the social position to their internal characteristics are evaluated, those attitudes seem to be related more to knowing what kinds of people they are and creating a mental representation about them rather than just to favor them (Andrews 2001: 15).

One of the most important claims of SJT is that members of disadvantaged groups have a tendency to perceive, understand and explain the conditions and regulations, which are against themselves and favor high-status groups, in a way that will allow them to maintain those conditions and regulations. Findings obtained from studies conducted within the context of TMT indicate that it is not against disadvantaged groups to support the system. The system satisfies their specific needs and motivations (self-esteem, continuity, and meaning). There are study findings showing that the tendency to support the system has a strong positive relationship with out-group favoritism (e.g., Jost and Burgess 2000: 209; Jost and Hunyady 2005: 260). An important reason for this can be seen as the fact that for many years, high-status groups have governed the system, and disadvantaged groups have equated those highstatus groups with the system.

Uludağ Üniversitesi Fen-Edebiyat Fakültesi Sosyal Bilimler Dergisi Uludağ University Faculty of Arts and Sciences Journal of Social Sciences Cilt: 20 Sayl: 37 / Volume: 20 Issue: 37 